\title{
Análise ambiental por meio de imagens orbitais: estudo de caso da Estação de Tratamento de Esgotos do município de São Manuel-SP.
}

Environmental Analysis through orbital images: case study of the Sewage Treatment Station of the municipality of São Manuel-SP.

Análisis Ambiental por medio de imágenes orbitales: estudio de caso de la Estación de Tratamiento de las aguas residuales del municipio de São Manuel-SP.

\section{Ronaldo Alberto Pollo} Doutor, Depto de Engenharia Rural/FCA/UNESP/Botucatu-SP. rapollo@fca.unesp.br

\section{Sérgio Campos}

Prof. Titular, Depto de Engenharia Rural/FCA/UNESP/Botucatu-SP. seca@fca.unesp.br

Gabriel Rondina Pupo da Silveira Doutorando em Agronomia/Energia na Agricultura/FCA/UNESP/Botucatu-SP. gabrielrondina@hotmail.com 


\section{INTRODUÇÃO}

A Lei do Saneamento Básico 11.445/2007 (BRASIL, 2007) estabeleceu diretrizes nacionais para o saneamento básico, visando além de outras, uma melhora na rede de tratamento de esgoto adequado, incentivando os municípios na construção de Estações de Tratamento de Esgotos de águas servidas, vindo a contribuir com a saúde pública contra a disseminação de doenças através do contato direto com água contaminada com dejetos, que em muitos casos são despejados no solo, nascentes, córregos e rios sem um tratamento adequado.

A natureza tem a capacidade de decompor a matéria orgânica presente nos corpos hídricos, mas quando estão presentes uma grande quantidade de efluentes, exige um tratamento mais eficaz em uma Estação de Tratamento de Esgoto (ETE) que, basicamente, reproduz a ação da natureza de maneira mais rápida (VON SPERLING, 1996).

As ETES tem como objetivo tratar o esgoto sanitário que é gerado através da utilização da água pelo homem. Segundo Lins (2010), são empreendimentos de suma importância para o sucesso de um plano de saneamento, sem elas certamente haveria um número maior de vítimas de doenças hídricas.

Muitos municípios começaram a construir suas Estações de Tratamento de Esgotos e encontrando-se hoje em funcionamento, mas alguns desses empreendimentos embora muito úteis para a saúde pública, vieram causar desconforto a população e alguns impactos e prejuízos aos recursos hídricos, por localizarem-se próximos as áreas urbanizadas, não contemplando o esgotamento sanitário de alguns bairros e muitas vezes ocupando áreas destinadas as APPs.

A utilização de Imagens de satélite tem contribuído para o estudo do meio ambiente, revelando através de análises temporais, riquezas de informações que poderão ser utilizadas para a formação do conhecimento e entendimento para uma melhor gestão do território.

\section{OBJETIVOS}

O objetivo deste trabalho foi avaliar o impacto ambiental utilizando imagens de satélite através da ferramenta atual Google Earth Pro e visitas a campo para visualização e compreensão dos problemas ambientais nas áreas circunvizinhas da Estação de Tratamento de Esgotos do município de São Manuel-SP.

\section{MATERIAL E MÉTODOS}

A Estação de Tratamento de Esgotos do município de São Manuel-SP, está situada nas coordenadas geográficas $48^{\circ} 34^{\prime} 44^{\prime \prime}$ de longitude Oeste do meridiano de Greenwich e $22^{\circ} 43^{\prime} 05^{\prime \prime}$ de latitude Sul da linha do Equador terrestre. O município de São Manuel-SP, possui uma população de 40.532 habitantes segundo (IBGE, 2016). 
Foram utilizadas imagens de satélite em duas datas de aquisição do banco de imagens do Google Earth Pro, por apresentarem com o recurso visual da ferramenta zoom, uma melhor resolução espacial, onde foi visualizada a área dando início ao processo de interpretação sob tela do computador na qual, foi calculada algumas distâncias em relação ao empreendimento (ETE) e seu entorno nas datas de 03/07/2008, mostrando a localização e o início de sua instalação no município e a outra imagem de 17/06/2016, revelando o avanço da área urbana com novos loteamentos. Visitas a campo foram realizadas na eliminação da subjetividade e confirmação da verdade terrestre.

\section{RESULTADOS E DISCUSSÃO}

A Figura 1 mostra a ETE do município de São Manuel-SP e seu entorno na data de 03/07/2008, com início de funcionamento com apenas duas lagoas e as outras quatro ainda em fase de construção.

Figura 1: Estação de Tratamento de Esgotos (A); e áreas em seu entorno.

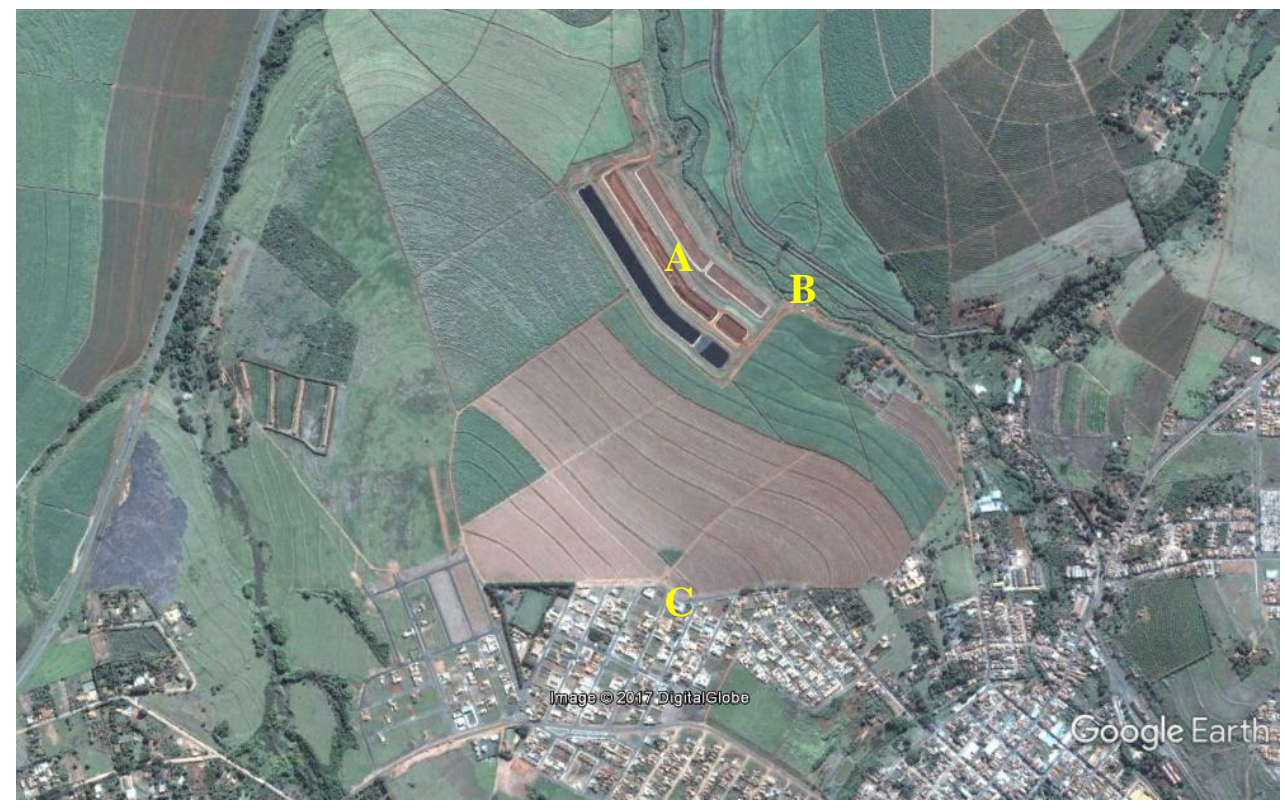

Fonte: Google Earth Pro (2017).

A referida obra representada por (A) na Figura 1, apresentou evidências de conflito de uso de solo, avançando sobre Áreas de Preservação Permanentes em (B) e estando muito próximo de um bairro da área urbana denominada Jardim Bela Vista (C), onde moradores demonstram grande insatisfação e reclamam que após a instalação da ETE, houve um aumento no aparecimento de vetores e odores desagradáveis são notados com freqüência.

A Figura 2 datada em 17/06/2016, retrata o avanço de novos loteamentos como o Nova Conquista II (D) e o bairro Aguiar (E) a menos de 500 metros da ETE (A) que não tratará os efluentes domésticos gerados pelos referidos bairros, pois estes, não contemplam a passagem 
do seu encanamento pela Estação de Tratamento onde terão seu destino final, despejados "in natura" em outro córrego (F), gerando impacto negativo e a queda da qualidade deste recurso hídrico.

Figura 2: Avanço dos loteamentos, Nova Conquista II (D) e bairro Aguiar (E).

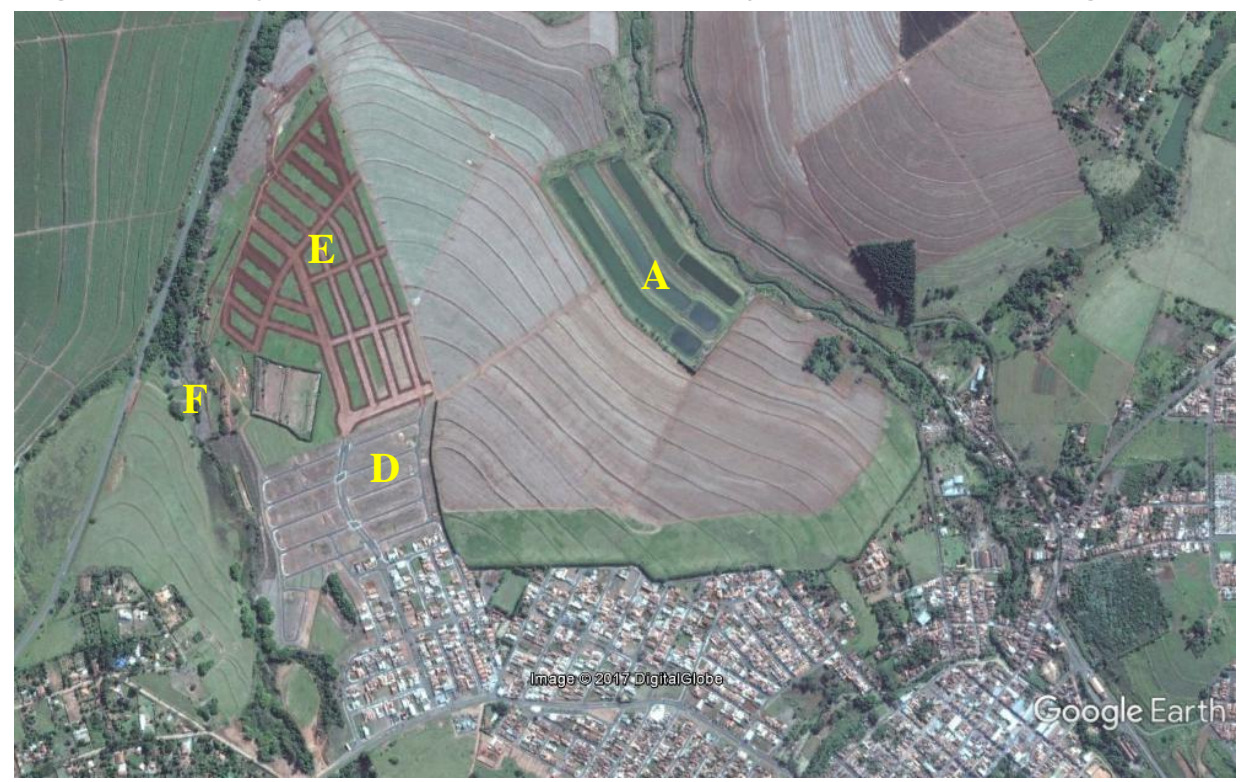

Fonte: Google Earth Pro (2017).

Do ponto de vista ambiental, econômico e social, todo o processo de licenciamento de atividades de uma ETE, deveria atender toda a área urbanizada existente com menor abrangência possível de impactos negativos e contemplar uma possível expansão urbana futura, devendo estar localizada mais adiante em direção ao rio e mais distante possível das áreas urbanizadas ou outras alternativas locacionais com menores impactos, não podendo se transformar num fator limitante para o crescimento do mercado imobiliário e de novos loteamentos nesta área.

\section{CONCLUSÃO}

A utilização das imagens orbitais de alta resolução espacial em duas datas de aquisição e visitas a campo, foram úteis na visualização e compreensão da dimensão dos problemas ambientais apresentados nas áreas circunvizinhas da Estação de Tratamento de Esgotos do município de São Manuel-SP, mediante a utilização do solo, emissão atmosférica de gases e conservação dos recursos hídricos.

\section{REFERÊNCIAS BIBLIOGRÁFICAS}

BRASIL. LEI N ${ }^{\circ} 11.445$ de 05 de Janeiro de 2007. Estabelece diretrizes nacionais para o saneamento básico; altera as Leis $n^{\text {os }} 6.766$, de 19 de dezembro de 1979, 8.036, de 11 de maio de 1990, 8.666, de 21 de junho de 1993, 8.987, de 13 de fevereiro de 1995; revoga a Lei n⒍528, de 11 de maio de 1978; e dá 
outras providências. Presidência da República. Brasília, 5 de janeiro de $2007 ; 186^{\circ}$ da Independência e $119^{\circ}$ da República.

GOOGLE EARTH PRO. Google Inc, 2016. Disponível em: <earth.google.com/>. Acesso em: 15 fev. 2017.

IBGE. Instituto Brasileiro de Geografia e Estatística. Cidades. Disponível em:< http://cidades.ibge.gov.br/xtras/perfil.php?lang=\&codmun=355010\&search=sao-paulo|sao-manuel>. Acesso em: 13 mai 2017.

LINS, G. A. Impactos Ambientais em Estações de Tratamento de Esgotos (ETEs). 2010. 285f.

(Mestrado em Engenharia Ambiental) - Escola Politécnica e Escola de Química, Universidade Federal do Rio de Janeiro, Rio de Janeiro, 2010.

VON SPERLING, M. Introdução à Qualidade das Águas e ao Tratamento de Esgotos - Princípios do Tratamento Biológico de Águas Residuárias. 2ª Ed. Rev. Belo Horizonte: UFMG/DESA, v.1, 1996. 243p. 